\title{
PENGGUNAAN GANJA DALAM ILMU PENGOBATAN MENURUT UNDANG- UNDANG NOMOR 35 TAHUN 2009 TENTANG NARKOTIKA
}

\author{
0leh \\ Enik Isnaini \\ Dosen Fakultas Hukum Universitas Islam Lamongan
}

\begin{abstract}
Abstrak
Narkoba adalah zat atau obat yang berasal dari tanaman atau bukan tanaman, baik sintesis maupun semi sintesis yang dapat menyebabkan penurunan atau perubahan kesadaran diri, hilangnya rasa sakit dan dapat menyebabkan ketergantungan. Yang terbagi atas beberapa golongan menurut jenis, turunan dan efeknya.Ganja sendiri merupakan tumbuhan budidaya penghasil serat, namun lebih dikenal dengan kandungan zat narkotika yang terdapat pada bijinya, yaitu tetrahidrokanabinol (THC, tetra-hydro-cannabinol) yang dapat membuat pemakainya mengalami euphoria (rasa senang yang berkepanjangan tanpa sebab). Namun ganja sendiri juga berguna dalam dunia kesehatan sebagai obat bius atau penenang untuk penghilang rasa sakit pada pasien yang akan melakukan operasi, terapi ataupun dalam tahap penyembuhan.Penggunanaan ganja dalam takaran yang tak tepat dan sembarangan bisa menyebabkan banyak masalah kesehatan, itulah sebabnya penggunaan ganja dalam proses penyembuhan dibidang kesehatan belum dapat diterapkan secara umum di Indonesia, serta pandangan masyarakat akan ganja sebagai barang yang haram hukumnya untuk dikonsumsi. Penyalahgunaan tersebut tentunya merupakan tindakan kejahatan yang tidak sesuai dengan aturan aturan yang berkaitan dengan narkotika yang diatur dalam Undang Undang nomor 35 tahun 2009 tentang Narkotika. Dalam undang-undang tersebut mengatur tentang semua yang berhubungan dengan narkotika mulai dari pengertian, jenis-jenis, zat apa saja yang terkandung didalamnya, manfaat, efek yang ditimbulkan, golongan-golongan narkotika, dan sanksi pidana yang dijatuhkan kepada para pelanggar yang menyalahgunakan narkotika.Maka dari itu, masyarakat diminta terus berhati-hati dengan pergaulan sekitar agar tidak ikut terjerumus dalam dunia narkotika yang membahayakan kesehatan tubuh hingga membahayakan nyawa bagi para penggunanya.
\end{abstract}

Kata Kunci : Ganja, Dalam Ilmu Pengobatan, Undang - undang no.35 Tahun 2009.

\section{A. Pendahuluan}

\section{Latar Belakang}

Narkoba merupakan singkatan dari narkotika dan obat berbahaya. Selain narkoba sinonim yang diperkenalkan oleh Kementerian Kesehatan juga disebut Napza yang merupakan singkatan dari narkotika, psikotropika, dan zat adiktif.

Kedua istilah tersebut baik "narkoba" ataupun "napza", mengacu pada suatu senyawa yang memiliki risiko kecanduan bagi penggunanya. Menurut ahli kesehatan, narkoba sebenarnya adalah senyawa psikotropika yang bisa gunakan untuk membius pasien saat hendak menjalanioperasi atau obat-obatan untuk penyakit syaraf.Namun saat ini persepsi itu disalahartikan akibat penggunaan di luar fungsi dan dosis yang dianjurkan.

Narkoba adalah zat atau obat yang berasal dari tanaman atau bukan tanaman, baik sintetis maupun semi sintetis yang dapat menyebabkan penurunan atau perubahan kesadaran diri, hilangnya rasa sakit dan dapat menyebabkan ketergantungan (Undang-Undang No. 35 tahun 2009). Narkotika dibagi menjadi dua golongan sebagaimana tertulis dalam 
lampiran 1 undang-undang tersebut. Yang termasuk jenis narkotika adalah:

1) Tanaman papaverin, opium mentah, opium masak (candu, jicing, jicingko), opium obat, morfina, kokaina, ekgonina, tanaman ganja, dan damar ganja.

2) Garam-garam dan turunan-turunan dari morfin dan kokain, serta campuran-campuran dan sediaansediaan yang mengandung bahan tersebut di atas.

Psikotropika adalah zat atau obat, baik alamiah maupun sintetis bukan narkotika, yang berdampak psikoaktif melalui pengaruh pada susunan sistem saraf pusat yang menyebabkan perubahan pada aktivitas mental dan perilaku (Undang-Undang No. 5/1997).

Tersedia empat golongan psikotropika menurut undang-undang tersebut, namun setelah diundangkannya UU No. 35 tahun 2009 tentang narkotika, maka psikotropika golongan I dan II dimasukkan ke dalam golongan narkotika. Dengan demikian saat ini apabila membahas tentang psikotropika golongan III dan IV sesuai Undang-Undang No. 5 Tahun 1997

Ganja (Cannabis sativa atauCannabis indica) adalah tumbuhan budidaya penghasil serat, namun lebih dikenal sebagai obat psikotropika karena adanya kandungan zat tetrahidrokanabinol (THC, tetra-hydro-cannabinol yang dapat membuat pemakainya mengalami euforia (rasa senang yang berkepanjangan tanpa sebab). Tanaman ganja biasanya dibuat menjadi rokok mariyuana.

Tanaman semusim ini tingginya dapat mencapai 2 meter. Berdaun menjari dengan bunga jantan dan betina ada di tanaman berbeda (berumah dua). Bunganya kecil-kecil dalam dompolan di ujung ranting. Ganja hanya tumbuh di pegunungan tropis dengan ketinggian di atas 1.000 meter di atas permukaan laut.
Berdasarkan Undang-Undang No. 22 Tahun 1997 yang memasukkan ganja ke dalam kategori narkotika golongan $\mathrm{I}$. Penggunaan ganja terancam hukuman maksimal 10 tahun penjara.sedangkan menurut uu no.35 tahun 2009 tentang narkotika diancam dengan hukuman paling lama 12 tahun.

Pemerintah juga sudah pernah mengatur secara khusus pertanian ganja lewat Peraturan Pemerintah No. 1 Tahun 1980 tentang Ketentuan Penanaman Papaver, Koka, dan Ganja. Berdasarkan PP ini lembaga pendidikan atau lembaga pengetahuan bisa menanam ganja setelah memperoleh izin. Lembaga ini harus membuat laporan setiap enam bulan sekali mengenai lokasi, luas tanaman, dan hasil. Kalau ada kehilangan, lembaga dimaksud harus melapor ke polisi.Secara umum ganja tidak menimbulkan ketagihan (withdrawal) seperti halnya morfin. Bila seorang pecandu morfin memutuskan untuk berhenti, dia akan merasakan rasa sakit di tubuh, lazim disebut sakaw. Dari studi literatur, jelas Tomi, ganja hampir sama dengan rokok. Ganja tidak pernah menimbulkan overdosis dan tidak menimbulkan sifat agresif. Tetapi semua itu harus dibuktikan lewat penelitian pungkasnya.

Selain efek negatif, ganja memiliki dampak positif seperti tumbuhan yang ramah lingkungan, anti hama, mudah ditanam, dan memiliki banyak manfaat. Dengan menurunkan kadar THC (Tetrahydrocannabinol) ganja dapat dimanfaatkan untuk membuat bahan tekstil, kertas, bahan pembuat makanan. Sementara kadar THC ganja yang tumbuh di Indonesia belum terukur.THC merupakan salah satu zat yang dapat menghilangkan rasa sakit, misalnya pada penderita glukoma.THC memiliki efek analgesic, yang dalam dosis rendahnya saja sudah berdampak bagi pasien. apabila kadar THC diperkaya, dapat menjadi lebih berguna untuk tujuan pengobatan. Selain itu dimasyarakat tradisonal opium, kokain, 
dan ganja, digunakan sebagai pengobatan tradisional. Dan dapat digunakan sebagai penyedap masakan seperti di Aceh.

karena sifatnya sebagai halusinogen dan dapat menimbulkan euforia, efek negatif ganja adalah membuat orang menjadi malas. Efek paling buruk dari ganja karena menjadikan reaksi pemakai lebih lambat, dan peganja cenderung kurang waspada.

Soal kemungkinan dilegalkannya ganja, dengan penggunaan yang diawasi dan dibatasi bagi pengobatan Pengguna ganja demi kepentingan penyembuhan atau obat seperti di beberapa negara telah dilegalkan dengan catatan tidak disalah gunakan.

2. Tujuan Penelitian

Berdasarkan rumusan masalah diatas, maka penulisan penelitian ini bertujuan untuk :

c. Untuk mengetahui pengaturan tentang penggunaan ganja untuk pengobatan.

Untuk mengetahui sanksi terhadap pengguna ganja selain untuk pengobatan.

B. Metode Penelitian

1. Type Penelitian

Metode penelitian yang dipakai adalah metode penelitian hukum normatif atau peneltian hukum kepustakaan yaitu penelitian hukum yang dilakukan dengan cara meneliti undang undang dan data sekunder.bahan -bahan tersebut disusun secara sistematis untuk memepercepat dalam mengambil simpulan dari permasalahan yang diteliti.

2. Pendekatan Masalah

Pendekatan masalah penelitian ini menggunakan pendekatan yuridis normatif.
Pendekatan ini ialah pendekatan terhadap peraturan perundangundangan yang ada.

Selain itu digunakan pendekatan yang lainnya guna mempermudah analisia ilmiah yang dibutuhkandalam permasalahan ini dalam pendekatan penelitan yuridis normatif.

3. Bahan Hukum

Bahan hukum dari penelitian hukum normatif yang dikaji adalah bahan hukum yang berisi peraturan normative yaitu bahan-bahan hukum yang terdiri dari bahan hukum primer dan sekunder yaitu:

c. Bahan Hukum Primer

1) Undang-Undang Dasar Republik Indonesia Tahun 1945.

2) Kitab Undang-Undang Hukum Pidana (KUHP).

3) Undang-Undang No. 35 Tahun 2009 Tentang Narkotika

4) Tentang Pelaksanaan Undang - Undang Nomor 35 Tahun 2009

5) Tentang NarkotikaPeraturan Pemerintah Republik Indonesia Nomor 40 Tahun 2013

d. Bahan Hukum Sekunder

1) Buku-buku tentang Narkotika.

2) Website resmi yang membahas permasalahan ini.

1. Metode Pengumpulan Data Dalam penelitian ini yang digunakan yang digunakan adalah penelitian hukum normatif atau penelitian hukum kepustakaan, maka dalam pengumpulan bahan hukum penulis menggunakan bahan hukum primer maupun bahan hukum sekunder untuk 
membahas permasalahan dalam penelitian ini.Dengan begitu akan mempermudah dalam menyelesaikan permasalahan yang ada dan dapat mempercepat proses penulisan penelitian ini.

2. Analisis yang digunakan adalah analisis deskripstif, yang di mulai dengan mengelompokkan data yang dilakukan secara induksi sehingga memberikan hasil secara sempurna, untuk memperoleh informasi yang akurat dengan begitu penelitian dapat lebih terfokus pada masalah yang spesifik.selain itu dapat memudahkan penulis dalam menganalisa data yang sudah lengkap dan yang telah dikumpulkan.

\section{Hasil Penelitian dan Pembahasan}

Peraturan Penggunaan Ganja Dalam Ilmu Pengobatan Menurut Undang Undang nomor 35 Tahun 2009 Tentang Narkotika.

Kasus Fidelis Ari

Sudewarto yang ditangkap karena kepemilikan ganja untuk pengobatan istrinya mendapat sorotan dari lembaga swadaya masyarakat Lingkar Ganja Nusantara (LGN). Menurut LGN yang melakukan dokumentasi sejak 2010, ganja berkhasiat dalam pengobatan penyakit mematikan. Namun, kata LGN, penggunaan ganja dalam medis masih tabu di Indonesia. LGN berharap pemerintah meninjau ulang kebijakan narkotika.

Pada 19 Februari 2017, BNN menangkap Fidelis Ari Sudewarto, warga Kabupaten Sanggau, Kalimantan Barat. Dia dituduh menanam 39 batang ganja di rumahnya. Ekstrak ganja itu dia gunakan untuk pengobatan istrinya yang terkena penyakit syringomyelia atau kista di sumsum tulang belakang setelah perawatan konvensional dan alternative gagal.

Karena tindakannya itu, Fidelis ditahan selama 32 hari. Ketika suaminya ditahan, Yeni tidak mendapatkan pengobatan ekstrak ganja sehingga meninggal. Meski menggunakan ganja untuk pengobatan istrinya, Fidelis tidak ikut menggunakan ganja apalagi menjualnya.

Sementara kepala BNN Jendral Budi Waseso menambahkan seandainya riset medis Kementerian Kesehatan terbukti ekstrak ganja bermanfaat untuk pengobatan, nanti akan ada aturan khusus untuk hal tersebut. "Nanti diatur dalam Undang-Undang cara menggunakan bagaimana, siapa yang boleh menggunakan, yakinlah itu, kita tidak boleh sembarangan. Kalau untuk kebaikan pastilah kami ikuti," katanya.

Dalam sidang perdananya oleh jaksa penuntut umum, Erhan Lidiansyah menjelaskan Fidelis Ari dikenakan tiga pasal alternatif. Sejak pagi, ruang sidang tampak penuh sesak pengunjung yang ingin menyaksikan proses persidangan perdana Fidelis Ari secara langsung. Fidelis Ari tiba di Pengadilan Negeri (PN) Sanggau, dengan pengawalan ketat oleh petugas menggunakan kendaraan roda empat milik Kejaksaan Negeri Sanggau untuk menjalani sidang perdananya, sekitar pukul 10.45 Wib. 
"Dalam dakwaannya, Fidelis dikenakan tiga pasal yaitu, dakwaan pertama pasal 113 ayat 2, dakwaan kedua yaitu pasal 111 ayat 2 dan dakwaan alternatif ketiga pasal 116 ayat 1 dengan ancaman 5 tahun hingga 20 tahun penjara," ungkap Jaksa Penuntut Umum, Erhan Lidiansyah, kepada wartawan saat ditemui usai sidang.

Lanjutnya lagi, Erhan Lidiansyah mengatakan saat ini pihaknya tetap mengikuti prosedur hukum. "Dakwaan tadi kita tetapkan berdasarkan fakta, dimana ganja tersebut digunakan terdakwa untuk mengobati istrinya, kemudian dari cara dia mengolahnya yang kita katagorikan terdakwa memproduksi menjadi ekstrak yang sebelumnya dia dapatkan dari membeli kepada orang lain," ujarnya.

Di dalam undang - undang nomer 35 tahun 2009 tentang narkotika di bab ix yang menjelaskan tentang pengobatan dan rehabilitasi, di bagian satu di jelaskan mengenai pengobatan dan diatur dalam pasal 53 ayat 1 sampai dengan ayat 3 yang berbunyi sebagai berikut.

(1) Untuk kepentingan pengobatan dan berdasarkan indikasi medis, dokter dapat memberikan Narkotika Golongan II atau Golongan III dalam jumlah terbatas dan sediaan tertentu kepada pasien sesuai dengan ketentuan peraturan perundang-undangan.

(2) Pasien sebagaimana dimaksud pada ayat (1) dapat memiliki, menyimpan, dan/atau membawa Narkotika untuk dirinya sendiri.
(3) Pasien sebagaimana dimaksud pada ayat (2) harus mempunyai bukti yang sah bahwa Narkotika yang dimiliki, disimpan, dan/atau dibawa untuk digunakan diperoleh secara sah sesuai dengan ketentuan peraturan perundang-undangan.

Bak pedang bermata dua. Demikianlah jika kita menggunakan ganja sebagai obat medis di beberapa negara, termasuk Indonesia. Di satu sisi, penggunaan Cannabis sativa untuk pengobatan beberapa penyakit memang bermanfaat. Namun di sisi lain, legalitas hukum dilanggar dan efek samping akibat penggunaan ganja medis masih diperdebatkan.

Padahal, kebutuhan ganja sebagai salah satu obat dalam dunia medis sudah ada sejak berabad-abad lalu. Di dalam ganja, para peneliti menemukan komponen zat aktif yang kemungkinan bisa membantu pengobatan. Komponen itu ialah senyawa kimia yang disebut cannabinoids. Cannabinoids banyak ditemukan dalam ganja. Dua senyawa aktif cannabinoids yang sudah diteliti antara lain delta-9tetrahydrocannabinol (THC) dan cannabidiol (CBD).

Zat-zat tersebut konon bisa membantu menyembuhkan dan mengurangi gejala penyakit tertentu seperti radang usus (inflammatory bowel disease/(BD), kanker, juga dapat meningkatkan nafsu makan pada penderita HIV/AIDS, hepatitis C, gangguan stres, pascatrauma, glaukoma, epilepsi, dan beberapa penyakit lain.

Meski penelitian soal manfaat ganja untuk medis terhitung belum begitu banyak, namun pada beberapa studi kasus kecil, penggunaan ganja pada pasien kanker dikabarkan bisa mengurangi mual dan pusing usai menjalani kemoterapi. 
Para penderita kanker biasanya 'menikmati' pengobatan ganja melalui makanan seperti kue. Tetap, pemakaian ganja dalam makanan itu harus menggunakan izin tertentu. Pengawasan ketat atas penggunaan ganja sebagai obat medis, tak lepas dari efek samping yang mungkin ditimbulkan. Pada kondisi pasien yang berbeda, penggunaan ganja bisa membuat perubahan mood seperti mendadak ceria, santai, mengantuk, atau justru jadi cemas. Efek samping ini bisa bertahan 1 hingga 3 jam.

Sangat sulit memprediksi efek ganja medis pada pasien karena tanaman ganja punya banyak senyawa aktif. Efek bisa dirasakan berbeda-beda berdasarkan waktu pemakaian ganja dan dosis yang digunakan.

Namun meski makin banyak negara yang melegalkan ganja untuk kepentingan medis, di Indonesia ganja masih termasuk narkotika kelas I dan dilarang penggunaannya dalam bentuk apapun. ${ }^{34}$

\section{SANKSI TERHADAP PENGGUNAAN GANJA SELAIN UNTUK PENGOBATAN MENURUT UNDANG - UNDANG NOMOR 35 TAHUN 2009 TENTANG NARKOTIKA}

Isu mengenai pemakaian ganja bisa dibilang selalu menarik untuk dibahas. Bahkan ada beberapa masyarakat yang pernah melakukan upaya untuk melegalisasi ganja di Indonesia. Tapi, berdasarkan peraturan perundangundangan di Indonesia, ganja masih termasuk sebagai barang yang ilegal. Konsekuensinya, warga Indonesia yang ketauan menggunakan ganja, bisa dijerat sanksi dan tindakan. Sanksi dan tindakan ini juga tentunya berlaku bagi semua warga Indonesia, baik yang sudah dewasa, maupun pelajar. Ganja merupakan salah satu jenis

\footnotetext{
${ }^{34}$ https://kumparan.com/niken-nurani/mengulaspenggunaan-ganja-di-dunia-medis
}

narkotika golongan I sebagaimana disebutkan dalam Daftar Narkotika Golongan I angka 8 Lampiran I Undang-Undang No. 35 Tahun 2009 tentang Narkotika ("UU Narkotika"): UU Narkotika sendiri tidak mencantumkan istilah "mengkonsumsi". Beberapa pasal yang dapat kita temui dalam UU Narkotika ini mencantumkan istilah seperti: menggunakan, memiliki, menyimpan, menguasai, menyediakan, menawarkan untuk dijual, menjual, membeli, menerima, menjadi perantara dalam jual beli, menukar, atau menyerahkan. Namun, bisa diartikan, "mengonsumsi" adalah memiliki dan menggunakan ganja untuk kepentingan pribadi, serta kepemilikan dan penggunaan ganja tersebut tidak termasuk sebagai yang diperbolehkan oleh UU Narkotika. Tak hanya itu, biasanya, "mengonsumsi" ganja diartikan bahwa ganja sudah dalam bentuk punting / linting ganja siap pakai. ${ }^{35}$

Atas perbuatan memiliki ganja, orang tersebut dapat dipidana sebagaimana terdapat dalam Pasal 112 Undang Undang Nomor 35 tahun 2009 tentang Narkotika, yang berbunyi: (1) "Setiap orang yang tanpa hak atau melawan hukum memiliki, menyimpan, menguasai, atau menyediakan Narkotika Golongan I bukan tanaman, dipidana dengan pidana penjara paling singkat 4 (empat) tahun dan paling lama 12 (dua belas) tahun dan pidana denda paling sedikit Rp. 800.000.000,00 (delapan ratus juta rupiah) dan paling banyak Rp. 8.000.000.000,00 (delapan miliar rupiah). (2) Dalam hal perbuatan memiliki, menyimpan, menguasai, atau menyediakan Narkotika Golongan I bukan tanaman sebagaimana dimaksud pada ayat (1) beratnya melebihi 5 (lima)

\footnotetext{
${ }^{35} \mathrm{https}$ //www.kaskus.co.id/thread/51d6aa8f1dd719 3411000009/gimana-sanksinya-kalaumengonsumsi-ganja-cekidot/
} 
gram, pelaku dipidana dengan pidana penjara seumur hidup atau pidana penjara paling singkat 5 (lima) tahun dan paling lama 20 (dua puluh) tahun dan pidana denda maksimum sebagaimana dimaksud pada ayat (1) ditambah $1 / 3$ (sepertiga)."

Kemudian, atas penggunaan narkotika jenis ganja ini, ia dapat disebut sebagai penyalahguna, yakni orang yang menggunakan narkotika tanpa hak atau melawan hukum.

Sebagai orang yang menggunakan narkotika tanpa hak atau melawan hukum, orang tersebut dapat dipidana berdasarkan Pasal 127 ayat (1) huruf a UU Narkotika yang mengatakan bahwa setiap penyalah guna narkotika golongan I bagi diri sendiri dipidana dengan pidana penjara paling lama 4 (empat) tahun. Jika penyalah guna tersebut dapat dibuktikan atau terbukti sebagai korban penyalahgunaan narkotika, penyalah guna tersebut wajib menjalani rehabilitasi medis dan rehabilitasi sosial.

Berikut beberapa pasal di dalam kitab undang undang hukum pidana (kuhp) yang menjelaskan tentang sanksi pidana bagi penyalahgunaan nerkotika.

\section{Pasal}

113

(2) Dalam hal perbuatan memproduksi, mengimpor, mengekspor, atau menyalurkan Narkotika Golongan I sebagaimana dimaksud pada ayat (1) dalam bentuk tanaman beratnya melebihi 1 (satu) kilogram atau melebihi 5 (lima) batang pohon atau dalam bentuk bukan tanaman beratnya melebihi 5 (lima) gram, pelaku dipidana dengan pidana mati, pidana penjara seumur hidup, atau pidana penjara paling singkat 5 (lima) tahun dan paling lama 20 (dua puluh) tahun dan pidana denda maksimum sebagaimana dimaksud pada ayat (1) ditambah 1/3 (sepertiga).

\section{Pasal}

(2) Dalam hal perbuatan menawarkan untuk dijual, menjual, membeli, menjadi perantara dalam jual beli, menukar, menyerahkan, atau menerima Narkotika Golongan I sebagaimana dimaksud pada ayat (1) yang dalam bentuk tanaman beratnya melebihi 1 (satu) kilogram atau melebihi 5 (lima) batang pohon atau dalam bentuk bukan tanaman beratnya 5 (lima) gram, pelaku dipidana dengan pidana mati, pidana penjara seumur hidup, atau pidana penjara paling singkat 6 (enam) tahun dan paling lama 20 (dua puluh) tahun dan pidana denda maksimum sebagaimana dimaksud pada ayat (1) ditambah $1 / 3$ (sepertiga).

\section{Pasal}

116

(2) Dalam hal penggunaan narkotika terhadap orang lain atau pemberian Narkotika Golongan I untuk digunakan orang lain sebagaimana dimaksud pada ayat (1) mengakibatkan orang lain mati atau cacat permanen, pelaku dipidana dengan pidana mati, pidana penjara seumur hidup, atau pidana penjara paling singkat 5 (lima) tahun dan paling lama 20 (dua puluh) tahun dan pidana denda maksimum sebagaimana dimaksud pada ayat (1) ditambah 1/3 (sepertiga).

\section{Pasal}

118

(2) Dalam hal perbuatan memproduksi, mengimpor, mengekspor, atau menyalurkan Narkotika Golongan II sebagaimana dimaksud pada ayat (1) beratnya melebihi 5 (lima) gram, pelaku dipidana dengan pidana mati, pidana penjara seumur hidup, atau pidana penjara paling singkat 5 (lima) tahun dan paling lama 20 (dua puluh) tahun dan pidana denda maksimum sebagaimana dimaksud pada ayat (1) ditambah 1/3 (sepertiga).

Pasal

119

(2) Dalam hal perbuatan menawarkan untuk dijual, menjual, membeli, menerima, menjadi perantara dalam jual beli, menukar, atau menyerahkan Narkotika Golongan II sebagaimana dimaksud pada ayat (1) beratnya melebihi 5 (lima) gram, pelaku dipidana dengan pidana mati, pidana penjara seumur hidup, atau pidana 
penjara paling singkat 5 (lima) tahun dan paling lama 20 (dua puluh) tahun dan pidana denda maksimum sebagaimana dimaksud pada ayat (1) ditambah 1/3 (sepertiga).

\section{Pasal}

\section{1}

(2) Dalam hal penggunaan Narkotika terhadap orang lain atau pemberian Narkotika Golongan II untuk digunakan orang lain sebagaimana dimaksud pada ayat (1) mengakibatkan orang lain mati atau cacat permanen, pelaku dipidana dengan pidana mati, pidana penjara seumur hidup, atau pidana penjara paling singkat 5 (lima) tahun dan paling lama 20 (dua puluh) tahun dan pidana denda maksimum sebagaimana dimaksud pada ayat (1) ditambah 1/3 (sepertiga).

\section{Pasal}

132

(3) Pemberatan pidana sebagaimana dimaksud pada ayat (2) tidak berlaku bagi tindak pidana yang diancam dengan pidana mati, pidana penjara seumur hidup, atau pidana penjara 20 (dua puluh) tahun.

\section{Pasal}

133

(1) Setiap orang yang menyuruh, memberi atau menjanjikan sesuatu, memberikan kesempatan, menganjurkan, memberikan kemudahan, memaksa dengan ancaman, memaksa dengan kekerasan, melakukan tipu muslihat, atau membujuk anak yang belum cukup umur untuk melakukan tindak pidana sebagaimana dimaksud dalam Pasal 111, Pasal 112, Pasal 113, Pasal 114, Pasal 115, Pasal 116, Pasal 117, Pasal 118, Pasal 119, Pasal 120, Pasal 121, Pasal 122, Pasal 123, Pasal 124, Pasal 125, Pasal 126, dan Pasal 129 dipidana dengan pidana mati atau pidana penjara seumur hidup, atau pidana penjara paling singkat 5 (lima) tahun dan paling lama 20 (dua puluh) tahun dan pidana denda paling sedikit Rp2.000.000.000,00 (dua miliar rupiah) dan paling banyak Rp20.000.000.000,00 (dua puluh miliar rupiah).
Pasal

144

(2) Ancaman dengan tambahan 1/3 (sepertiga) sebagaimana dimaksud pada ayat (1) tidak berlaku bagi pelaku tindak pidana yang dijatuhi dengan pidana mati, pidana penjara seumur hidup, atau pidana penjara 20 (dua puluh) tahun.

\section{PENUTUP (KESIMPULAN) \\ 1. SIMPULAN}

Narkotika merupakan semua bahan obat yang mempunyai efek kerja yang bersifat membius, merangsang, ketagihan, dan menimbulkan daya berkhayal yang mempunyai banyak macam dan jenisnya, sehingga dapat digolongkan menurut kegunaannya. Awalnya bahan obat ini digunakan untuk bidang kesehatan dalam hal ini sebagai pereda rasa sakit untuk pasien yang akan menjalani operasi maupun pada proses terapi. Namun, ditangan orang yang tidak tepat bahan obat ini dipergunakan sebagai obat untuk menenangkan diri dan berhalusinasi yang akan membuat pemakainya merasa tidak memiliki beban apapun dalam hidup. Cara penggunaannya pun berbeda-beda tergantung jenisnya. Pada beberapa tahun lalu sempat dihebohkan dengan kasus penggunaan ganja sebagai media pengobatan oleh seorang suami kepada istri. Proses pengobatan itu berhasil menghilangkan rasa sakit yang diderita sang istri, namun pengobatan itu tidak didasari dengan resep dan anjuran dari dokter, sehingga sang suami ditangkap atas dasar kepemilikan ganja dan dikenakan Pasal 111 dan 116 UU nomor 35 tentang Narkotika atas dasar kepemilikan 39 batang pohon ganja. Akan tetapi pembelaan justru dilakukan oleh lembaga swadaya masyarakat yaitu Lingkar Ganja Nasional (LGN). Mereka menganggap bahwa apa yang dilakukan sang suami tidak lah salah, karena melakukan pengobatan kepada istri tanpa niat 
jahat dan telah menimbang segala resiko yang akan diterima.

Penggunaan ganja dalam ilmu kesehatan merupakan hal yang masih dianggap tabu oleh sebagian masyarakat di Indonesia. Selama ini ganja memiliki reputasi buruk dalam masalah kesehatan, karena disalah gunakan oleh pihak -pihak yang tidak bertanggung jawab. Ganja memberikan rasa kecanduan, rasa cemas, atau kerusakan pada otak yang berkaitan dengan ingatan. Ganja sendiri diatur dalam Undang Undang nomor 35 tahun 2009 tentang Narkotika. Sanksi-sanksi yang diberikan tidaklah ringan dan tergolong sangat berat karena hukuman terberatnya ialah hukuman mati bagi para Bandar dan pengedarnya.

\section{SARAN}

Bagi para pihak yang dianggap mempunyai kepentingan baik terhadap pengguanan ganja untuk kesehatan, diharapkan untuk melakukan penelitian lebih terperinci terhadap keuntungan dan manfaat yang sebenarnya dari ganja dalam bidang kesehatan. Dan juga memberikan informasi serta pembelajaran kepada masyarakat luas tentang apa itu ganja dan dampak yang akan ditimbulkan dari pengguanaan ganja yang tidak terkontrol.

Bagi masyarakat awam, sebaiknya jangan sampai mempunyai urusan apapun yang berkaitan dengan ganja walaupun terdapat unsur dan niat baik kita untuk pemanfaatan ganja, namun pemanfaatan ganja dalam dunia kesehatan di Indonesia belumlah maksimal dan dianggap melanggar hukum karena tidak ada aturan yang kuat dalam kegunaan ganja sebagai media untuk kesehatan.

\section{E. DAFTAR PUSTAKA}

- Kitab undang-undang hukum pidana.

- Undang undang nomor 35 tahun 2009 Tentang Narkotika

- http://halosehat.com/farmasi/aditif/ 20-jenis-jenis-narkoba-gambarefek-dampak-dan-pengertiannya (1 March,2015)

- https://id.wikipedia.org/wiki/Narko $\underline{\text { ba }}$

- http://www.seputarpendidikan.com/ 2017/01/10-pengertian-narkobamenurut-para-ahli.html

- $\quad$ http://www.seputarpendidikan.com/ 2017/01/10-pengertian-narkobamenurut-para-ahli.html

- http://halosehat.com/farmasi/aditif/ 20-jenis-jenis-narkoba-gambarefek-dampak-dan-pengertiannya

- https://id.wikipedia.org/wiki/Ilmu kesehatan_masyarakat

- https://kumparan.com/nikennurani/mengulas-penggunaanganja-di-dunia-medis

- https://www.merdeka.com/sehat/10 -manfaat-mengejutkan-ganjauntuk-kesehatan.html

- https://www.kaskus.co.id/thread/51 d6aa8f1dd7193411000009/gimanasanksinya-kalau-mengonsumsiganja-cekidot/ 